\title{
Web-Based School Library Information System with Wordpress Vocational High School
}

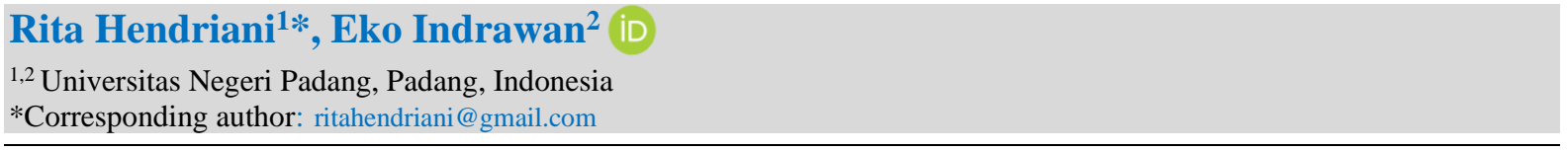

\begin{abstract}
Abstrak
Pengelolaan sistem informasi administrasi yang baik merupakan faktor penting dalam proses administrasi perpustakaan sekolah. Tujuan dari penelitian ini adalah untuk merancang sistem informasi perpustakaan sekolah berbais web dengan wordpress dan untuk mengimplementasikan sistem yang dirancang. Data-data yang digunakan dikumpulkan dengan menggunakan teknik observasi dan wawancara serta dokumentasi. Jenis metode pengembangan yang digunakan adalah Research and Develompment (R\&D). Model pengembangan yang digunakan adalah model waterfall. Prinsip pendekatan sistem yang diterapkan model ini terdiri dari lima tahap, yaitu analisis, disain, coding, pengujian serta implementasi \& maintenance. Sedangkan platform CMS yang digunakan adalah Wordpress serta software phpMyAdmin sebagai bahasa pemrograman dan MySQL sebagai manajemen basis data (pengelola database). Hasil penelitian menunjukkan bahwa sistem informasi perpustakaan sekolah berbasis web dengan wordpress yang dirancang dinyatakan valid dan praktis untuk dapat digunakan sebagai sistem informasi perpustakaan sekolah. Secara keseluruhan, sistem informasi perpustakaan sekolah berbasis web ini akan mampu memberikan layanan perpustakaan yang lebih baik bagi siswa, guru dan staf. Sehingga keberadaan sistem informasi perpustakaan sekolah berbasis web dengan wordpress memberikan beberapa manfaat dalam proses pelaksanaan layanan perpustakaan.
\end{abstract}

Kata kunci: Sistem Informasi, Perpustakaan dan Wordpres

\section{Abstract}

Management of a good administrative information system is an important factor in the school library administration process. The purpose of this research is to design a web-based school library information system with wordpress and to implement the designed system. The data used were collected using observation and interview techniques and documentation. The type of development method used is Research and Development $(R \& D)$. The development model used is the waterfall model. The principle of the system approach applied by this model consists of five stages, namely analysis, design, coding, testing and implementation \& maintenance. While the CMS platform used is Wordpress and phpMyAdmin software as a programming language and MySQL as database management (database manager). The results showed that the web-based school library information system with wordpress designed was declared valid and practical to be used as a school library information system. Overall, this web-based school library information system will be able to provide better library services for students, teachers and staff. So that the existence of a web-based school library information system with wordpress provides several benefits in the process of implementing library services.

Keywords: Information System, Libraries and Wordpress

\section{INTRODUCTION}

The narrowing and rapid development of science and technology due to globalization is a reality that society must face (Susilana et al., 2020; Zubaidah, 2018). To get all the information that is happening in this whole hemisphere, distance and time are no longer a barrier (Arizona et al., 2020; Ediyanto, 2014). The social paradigm has changed so rapidly due to the sophistication of communication, information and transportation tools (Bergman \& Sams, 2012; Lase, 2019). Everything is easily accessible both through print and electronic media (Purmadi \& Surjono, 2016; Susanti, 2019). This has a big impact on the lifestyle of the community that easily influences each other (Faizah et al., 2020; Kusumayuni, 2021). Every school education unit, whether organized by the government or the community, must provide learning resources (Purwanti \& Krisnadi, 2020; Sabtaningrum et al., 2020). Therefore, it is impossible for education to be carried out properly if both the educational staff and students

$\begin{array}{ll}\text { History: } & \\ \text { Received } & \text { : February 08, } 2021 \\ \text { Revised } & \text { : February 12, } 2021 \\ \text { Accepted } & \text { : July 20, 2021 } \\ \text { Published } & \text { : October 25, 2021 }\end{array}$


are not supported by the necessary learning resources such as libraries, for the implementation of the teaching and learning activities concerned.

A library is a room, part of a building, or the building itself that is used to store books and other publications according to a certain arrangement for use by readers, not for sale (Jan \& Anwar, 2019; Nuha, 2014). Law of the Republic of Indonesia Number 43a of 2007 concerning the Library Article 23 paragraph (1) states the definition of a school library as follows: Each school / madrasah organizes a library that meets the national library standards by taking into account the national education standards (Akviansah, 2020; Prabowo \& Heriyanto, 2013). Vocational High School is a form of formal education that organizes vocational education at the secondary education level and aims to create students who have the skills and expertise to be independent, prepare their graduates to become middle-level workers who have knowledge, skills, expertise and finally have work readiness after completing their education (Jaya et al., 2016; Supriyadi, 2015; Uran, 2018). SMK Negeri 2 Padang Panjang is one of the vocational schools in the city of Padang Panjang, prepared to produce superior graduates and be ready to face global competition. However, some administrative activities at SMK N 2 Padang Panjang are still recorded manually. One of them is the school library administration system. The system that has not been computerized has resulted in limited access to book availability in the library, selection, borrowing and return of books by students.

Good management of administrative information systems is an important factor in the school library administration process (Masruri, 2004; Nuha, 2014; Nurendah \& Mulyana, 2013; Rodin, 2015). Because the recording is still manual, it takes a long time to copy, errors in the information on the availability of books, recording of borrowing and returning books and book information that are lost in the library often occur, especially with the number of books, magazines, journals and others of approximately 5000 pieces. The school library administration system that has not been computerized, often results in errors in recording and limited access to book availability in the library, selection, borrowing and returning of books by students, causing less effective services and resulting in the performance of librarians at SMKA Negeri 2 Padang Panjang not in accordance with what was expected. To be more effective and minimize errors, it is necessary to have a computerized library administration system in SMK N 2 Padang Panjang. But not only that, good design is also needed in order to accommodate the need for a good system. From the description of the background to the problem above, the writer can identify the problem as follows: Not yet integrated book data in the school library, so that their existence is irregular. There is no database-based data storage, so the process, processing and data retrieval takes a long time. Processing is slow, so that the resulting data and information are less accurate and actual. How to make a school library administration information system capable of displaying information quickly and accurately.

Based on the problem formulation above, the research objectives are: Producing a web-based school library information system for SMK Negeri 2 Padang Panjang and Knowing the validity and practicality of the web-based school library system for the SMK Negeri 2 Padang Panjang library. Information system is a system that provides information for management in making decisions and also for running company operations, where the system is a combination of people, information technology and organized procedures. Information system development which is often referred to as System Development as a system development process. The development of this system is defined as compiling a new system to replace the old system as a whole or improve the existing system. School libraries are libraries that are located and organized in schools to support the teaching and learning process at formal education institutions at the school level, both from the primary and secondary levels, for public and secondary schools. Web-based is information that can 
convey content in various forms of data and can be linked to various other information sources using web devices and resources to create good library services. Web-based library information can be accessed by admins /librarians, anywhere, anytime to get library information. Library information and content can be added easily.

\section{MATERIALS AND METHODS}

To solve real problems, a model is needed to combine development strategies consisting of design processes, methods, and tools. This strategy often leads to a process model or system design model. Therefore, the development of this digital library system uses the Waterfall Model development method (waterfall) (Arifah et al., 2019; Kramer, 2018; Pickett, 2018). It is called a waterfall because the process diagram is gradual like a multilevel waterfall. The waterfall model is a process model in developing software that has a systematic and sequential nature in building software (Kramer, 2018; Pickett, 2018). This method is a classic model that is systematic and easy to understand because it is sequential in the stages of building software. The stages are briefly as follows: The analysis phase aims to find the needs of users or users and the organization and analyze the conditions that exist at that time; the design stage. This stage aims to determine the detailed specifications of the information system components (human, hardware, software, network and data) and information products in accordance with the results of the analysis phase; the coding stage. This stage is the stage for finding or developing hardware and software (programming coding); system testing. Carry out testing and training as well as a move to a new system; implementation and maintenance stages. When the information system is in operation, maintenance is carried out. At this stage, process monitoring, evaluation and improvement is carried out if necessary. The stages in the waterfall method can be seen in the Figure 1.

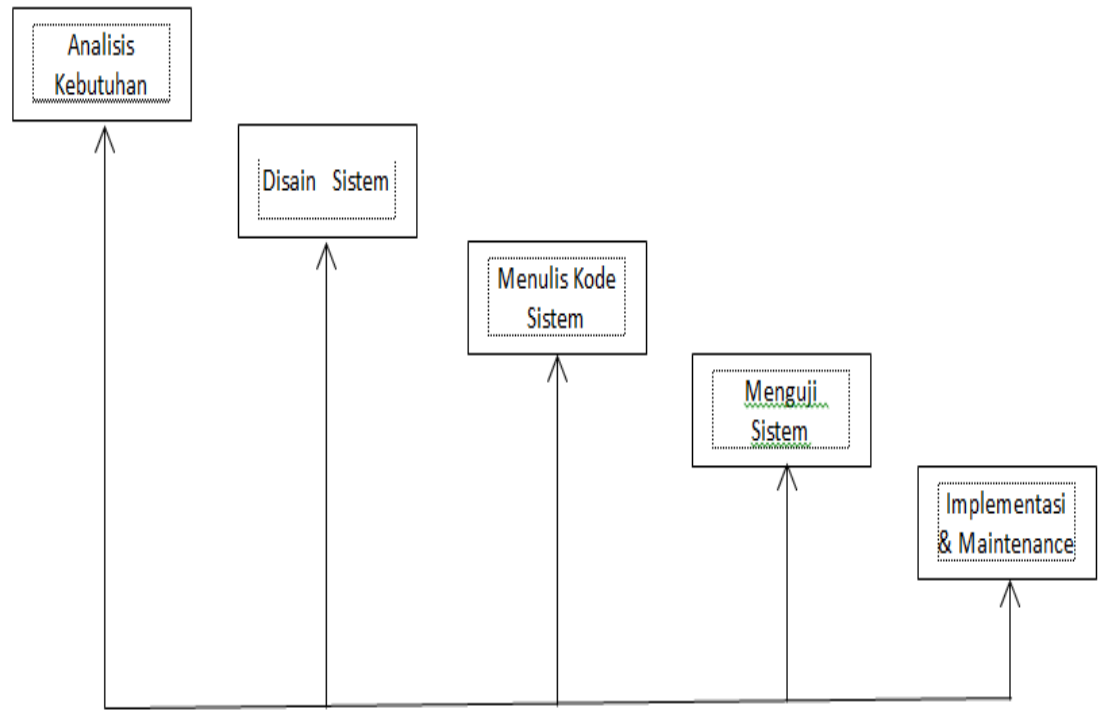

Figure 1. Waterfall Method Flow

Library is from the word Dasarpustaka. Library is Sanskrit which means book, manuscript, pinustaka. As a derived word, the library is formed by adding a per- prefix and asuffix. The formation of the per-prefix and the suffix-contains meanings related to the root word. Therefore, the library contains the meaning of activities related to the problem of libraries, books and manuscripts. These activities are carried out by a specific agency, specific institution or small unit of an institution. Library in general is a place where there are activities for gathering, processing, and disseminating all kinds of information, both printed 
and recorded in various forms. media such as books, magazines, newspapers, films, cassettes, tape recorders, videos, computers, and so on (Nuha, 2014; Rodin, 2015).

\section{RESULTS AND DISCUSSION}

\section{Result}

This research produces a Web-based School Library Information System for SMK N 2 Padang Panjang. The development of this system uses procedural development stages based on needs analyzes so that there are problems in the library known. To solve the problems that have been identified, solutions are proposed to help overcome these problems. Before the development is carried out, a background analysis is needed so that the development process can be carried out optimally. The results of the background analysis are used as a reference in the development stage. In this research, the development of a Web-based School Library Information System was carried out to solve problems in the library. The main function of this information system is as a means to assist in the library administration process and can improve the performance of librarians. This Web-Based School Library Information System with Wordpress was developed through several stages, including:

\section{Needs Analysis Stage}

This determination stage is carried out to get a picture of conditions in the field and analyze the requirements needed for the library information system development process. At this stage the following steps are taken. Identification of problems Based on observations made at the SMK N2 Padang Panjang library, it is known that there are several problems / obstacles in the administrative process in the school library. The problems found include the unintegrated data of books in the school library, no database-based data storage, so that the processing and data retrieval takes a long time and the processing is slow, so that the resulting data and information are less accurate and actual.

\section{Design stage}

At this stage, a web-based library information system prototype is made by designing the developed system design, arranging the menu to be displayed and planning the necessary navigation. The web-based school library information system was developed using wordpress with the necessary plugins for the library.

\section{Functional Requirements Analysis}

Based on the results of observations and interviews conducted with the librarian of SMK Negeri 2 Padang Panjang, it can be concluded that the functional requirements are as follows: System users are divided into four users, namely library members including school members who have registered as members, administrators, librarians and visitors; The system has three subsystems: admin, librarian, visitor.

\section{Hardware Requirements Analysis}

The hardware requirements of this system include: For servers in the form of a server computer that has been installed and configured according to minimum standards, namely Apache Web Server, PHP and MySQL as well as an internet connection. For clients, in the form of computers or laptops available web browser application and connected to the internet. 


\section{Software Requirements Analysis}

The software or software requirements of this system include: Windows 10 Operating System; XAMPP Version 1.8.1 as SQL Server; Web Browsers: Mozilla Firefox, Google Chrome. Based on the problem identification and analysis described above, it is concluded that the web-based school library information system is feasible to be developed. The next step is the product development stage.

\section{Development Stage}

The results of the analysis from the determination stage are used for the next stage, namely the development stage. At this stage the following steps are taken: Prototyping. At this stage, a web-based library information system prototype is made by designing the developed system design, arranging the menu to be displayed and planning the necessary navigation. The web-based school library information system was developed using wordpress with the necessary plugins for the library. Validation Stage Retrieval of data on the validity of web-based school library information system media is to use a validation sheet. Furthermore, the results of material validation were obtained from two validators. Media validation consisted of three aspects, namely aspects of appearance, aspects of use and aspects of function (Attachment 6). The validation results were obtained from the assessment of each indicator aspect given by the validator, then analyzed using the Aiken's $\mathrm{V}$ formula. From Table 4.2 it can be taken the overall validation average of the material, namely 0.9022 , so it can be concluded that the material is included in the "Valid" category.

\section{Evaluation Phase}

Practicality relates to the ease of use of the developed web-based library information system. Practicality data were obtained through a questionnaire filled out by the librarian. Before librarians use the system, librarians are taught how to use it and are given a manual for its use. The responses obtained from the librarian obtained from the practicality questionnaire regarding the web-based school library information system obtained responses between agree and strongly agree, so it can be concluded that this web-based library information system is practically used. From the questionnaire filling, the practicality rating is $90.89 \%$ (Appendix 8), so it can be concluded that the web-based library information system falls into the "Practical" category.

\section{Discussion}

This development research has resulted in a valid and practical web-based library system. This web-based library information system that has been developed can provide meaningful contributions in managing the library. Web-based information systems make it easy for librarians to provide services to students, teachers and the general public in fulfilling the required knowledge resources quickly and practically that cannot be done manually. Web-based school library information system can be opened by connecting to the internet network and without an internet network (intranet) by using localhost. To use a web-based library information system the librarian must have skills in managing the system. For this reason, training should be given to librarians when they want to switch from manual and use this library information system and prepare supporting devices such as computers that have adequate specifications, hosting subscription for applications that use the internet or their own local network. Librarians must be equipped with the ability and skills to implement a web-based library information system with the training held. The existence of a web-based school library information system provides several benefits for librarians of SMK Negeri 2 Padang Panjang, namely: the library database will be managed in a structured manner, reports are available and just displayed on the system and improve librarian performance. 
Overall, this web-based school library information system will be able to provide better library services for students, teachers and staff of SMK Negeri 2 Padang Panjang. So, the existence of a web-based school library information system with wordpress provides several benefits in the process of implementing library services at SMK Negeri 2 Padang Panjang including: Increase the effectiveness and efficiency of the librarian's time in serving students / teachers. Library information system, can create the effectiveness of each process starting from registration, borrowing, returning, procurement of books, and making reports. Simplify the library information system in presenting data reports on borrowing and returning books for each period to be more accurate.

A library is a room, part of a building, or the building itself that is used to store books and other publications according to a certain arrangement for use by readers, not for sale (Jan \& Anwar, 2019; Nuha, 2014). Law of the Republic of Indonesia Number 43a of 2007 concerning the Library Article 23 paragraph (1) states the definition of a school library as follows: Each school / madrasah organizes a library that meets the national library standards by taking into account the national education standards (Akviansah, 2020; Prabowo \& Heriyanto, 2013). Vocational High School is a form of formal education that organizes vocational education at the secondary education level and aims to create students who have the skills and expertise to be independent, prepare their graduates to become middle-level workers who have knowledge, skills, expertise and finally have work readiness after completing their education (Jaya et al., 2016; Supriyadi, 2015; Uran, 2018). SMK Negeri 2 Padang Panjang is one of the vocational schools in the city of Padang Panjang, prepared to produce superior graduates and be ready to face global competition. However, some administrative activities at SMK N 2 Padang Panjang are still recorded manually. One of them is the school library administration system. The system that has not been computerized has resulted in limited access to book availability in the library, selection, borrowing and return of books by students.

Good management of administrative information systems is an important factor in the school library administration process (Masruri, 2004; Nuha, 2014; Nurendah \& Mulyana, 2013; Rodin, 2015). Because the recording is still manual, it takes a long time to copy, errors in the information on the availability of books, recording of borrowing and returning books and book information that are lost in the library often occur, especially with the number of books, magazines, journals and others of approximately 5000 pieces. The school library administration system that has not been computerized, often results in errors in recording and limited access to book availability in the library, selection, borrowing and returning of books by students, causing less effective services and resulting in the performance of librarians at SMKA Negeri 2 Padang Panjang not in accordance with what was expected. To be more effective and minimize errors, it is necessary to have a computerized library administration system in SMK N 2 Padang Panjang. But not only that, good design is also needed in order to accommodate the need for a good system. From the description of the background to the problem above, the writer can identify the problem as follows: Not yet integrated book data in the school library, so that their existence is irregular. There is no database-based data storage, so the process, processing and data retrieval takes a long time. Processing is slow, so that the resulting data and information are less accurate and actual. How to make a school library administration information system capable of displaying information quickly and accurately.

\section{CONCLUSION}

Based on the results of research on the development of a web-based school library information system with wordpress that has been carried out, the following conclusions are obtained: The form of a web-based school library information system with wordpress for the 
library at SMK Negeri 2 Padang Panjang was developed in the form of an application that can facilitate the needs of librarians in managing library administration in a practical and structured manner. The Web-based library information system that was developed is valid and practical to be used to manage library administration. Based on the research conducted, the following are suggested: For schools it is suggested to take advantage of a web-based library information system to provide better service. For librarians. It is suggested that librarians who carry out library administration management can use this web-based library information system as an alternative system that can help streamline relatively little time and to help improve librarian performance. For other researchers. This research is still limited to one system development with wordpress only, it is recommended to be able to develop it in other applications.

\section{REFERENCES}

Akviansah, M. D. (2020). Perpustakaan Maya sebagai Sumber Belajar dan Penunjang Pembelajaran IPS secara Daring di Era Pandemi COVID-19. Jurnal Teori Dan Praksis Pembelajaran IPS, 5(2), 92-102. https://core.ac.uk/download/pdf/354310742.pdf.

Arifah, R. E. N., Sukirman, S., \& Sujalwo, S. (2019). Pengembangan Game Edukasi Bilomatika untuk Meningkatkan Hasil Belajar Siswa pada Mata Pelajaran Matematika Kelas 1 SD. Jurnal Teknologi Informasi Dan Ilmu Komputer, 6(6), 617. https://doi.org/10.25126/jtiik.2019661310.

Arizona, K., Abidin, Z., \& Rumansyah, R. (2020). Pembelajaran Online Berbasis Proyek Salah Satu Solusi Kegiatan Belajar Mengajar Di Tengah Pandemi Covid-19. Jurnal Ilmiah Profesi Pendidikan, 5(1), 64-70. https://doi.org/10.29303/jipp.v5i1.111.

Bergman, J., \& Sams, A. (2012). Flip Your Classroom: Reach Every Student in Every Class Every Day. International Society for Technology in Education.

Ediyanto, E. (2014). Pengembangan Model Penilaian Formatif Berbasis Web untuk Meningkatkan Pemahaman Konsep Fisika Siswa. Jurnal Pendidikan Sains, 2(2), 6375. http://dx.doi.org/10.17977/jps.v2i2.4499.

Faizah, N. okta, Sudatha, I. G. W., \& Simamora, A. H. (2020). Pengembangan Multimedia Pemelajaran IPA Untuk Meningkatkan Hasil Belajar. Journal of Education Technology, 4(1). https://doi.org/10.23887/jet.v4i1.24091.

Jan, S. U., \& Anwar, M. A. (2019). Emotional Intelligence, Library Use and Academic achievement of University Students. Journal of the Australian Library and Information Association, 68(1), 38-55. https://doi.org/10.1080/24750158.2019.1572482.

Jaya, H., Haryoko, S., \& Dirawan, G. D. (2016). Effectiveness the use of Virtual Laboratories in Improving Vocational Competence and Character Behavior for Students Vocational High School in Makassar. International Journal of Applied Engineering Research, 11(9), 6396-6401.

Kramer, M. (2018). Best practices in systems development lifecycle: An analyses based on the waterfall model. Review of Business \& Finance Studies, 9(1), 77-84. https://papers.ssrn.com/sol3/papers.cfm?abstract_id=3131958.

Kusumayuni, P. N. (2021). Pengembangan E-Book Berorientasi Ilmiah Pada Pelajaran IPA Sekolah Dasar Kelas V. http://dx.doi.org/10.23887/jisd.v5i1.32048.

Lase, D. (2019). Education and Industrial Revolution 4.0. Jurnal Handayani, 10(1), 48-62.

Masruri, A. (2004). Kualitas pelayanan perpustakaan (Studi kasus pada Perpustakaan IAIN Sunan Kalijaga Yogyakarta). Berkala Ilmu Perpustakaan Dan Informasi, 1(2), 4-12. https://journal.ugm.ac.id/bip/article/view/8346.

Nuha, U. (2014). Meningkatkan Kualitas Pelayanan Perpustakaan dengan Pendekatan 
Bilingual. Jurnal Perpustakaan Libraria, 2(1), 61-79. https://journal.iainkudus.ac.id/index.php/Libraria/article/view/1190.

Nurendah, Y., \& Mulyana, M. (2013). Analisis Pengaruh Kualitas Pelayanan Perpustakaan Terhadap Kepuasan dan Hubungannya dengan Loyalitas Mahasiswa. Jurnal Ilmiah Manajemen Kesatuan, 1(1), 93-112. https://tesniaga.stiekesatuan.ac.id/index.php/jimkes/article/view/258.

Pickett, D. (2018). Financial Waterfall Model Development. American Bankruptcy Institute Journal, $37(4)$, 46-107. https://search.proquest.com/openview/1ce2403b4dd1acc8c1500d24452b3d5f/1?pqorigsite $=$ gscholar $\& \mathrm{cbl}=33486$.

Prabowo, A., \& Heriyanto, H. (2013). Analisis Pemanfaatan Buku Elektronik (E-Book) Oleh Pemustaka di Perpustakaan SMA Negeri 1 Semarang. Jurnal Ilmu Perpustakaan, 2(2), 1-9. https://ejournal3.undip.ac.id/index.php/jip/article/view/3123.

Purmadi, A., \& Surjono, H. D. (2016). Pengembangan Bahan Ajar Berbasis Web Berdasarkan Gaya Belajar Siswa Untuk Mata Pelajaran Fisika. Jurnal Inovasi Teknologi Pendidikan, 3(2), 151-165. https://doi.org/10.21831/jitp.v3i2.8285.

Purwanti, E., \& Krisnadi, I. (2020). Implementasi Sistem Perkuliahan Daring Berbasis ICT Dalam Masa Pandemi Wabah Covid -19. Pascasarjana Program Magister Teknik Elektro Universitas Mercu Buana.

Rodin, R. (2015). Urgensi kualitas pelayanan perpustakaan perguruan tinggi. Al-Kuttab: Jurnal Perpustakaan Dan Informasi, 2(1), 1-20. http://194.31.53.129/index.php/alkuttab/article/view/547.

Sabtaningrum, F. E., Wiyokusumo, I., \& Leksono, I. P. (2020). E-book Tematik Terpadu Berbasis Multikultural Dalam Kegiatan SFH (School from Home). Jurnal Ilmiah Sekolah Dasar, 4(2), 153. https://doi.org/10.23887/jisd.v4i2.24796.

Supriyadi, E. (2015). Pendidikan dan Penilaian Karakter di Sekolah Menengah Kejuruan. Jurnal Cakrawala Pendidikan, 2. https://doi.org/10.21831/cp.v0i2.7590.

Susanti, B. H. (2019). Penggunaan Media Online Dalam Proyek Pembuatan Bahan Ajar Berbasis Web Pada Mata Kuliah Zoologi Vertebrata. Edusains, 11(1), 21-28. https://doi.org/10.15408/es.v11i1.7728.

Susilana, R., Herlina, \& Hadiapurwa, A. (2020). Pengembangan Website Pelatihan Program Intervensi Mandiri (PIM()) bagi Orangtua Anak Penyandang Autisme. Pedagogia $\begin{array}{llll}\text { Jurnal Ilmu } & \text { Pendidikan, }\end{array}$ https://doi.org/10.17509/pdgia.v18i2.31424.

Uran, L. L. (2018). Evaluasi implementasi KTSP dan Kurikulum 2013 pada SMK seKabupaten Belu, Nusa Tenggara Timur. Jurnal Penelitian Dan Evaluasi Pendidikan, 22(1), 1-11. https://doi.org/10.21831/pep.v22i1.13309.

Zubaidah, S. (2018). Mengenal 4C: Learning and Innovation Skills Untuk Menghadapi Era Revolusi Industri 4.0. 2nd Science Education National Conference, Oktober, 1-7. 